\title{
ARCTIC TRANSPORT ROUTES ON LAND, IN WATER AND AIR AREAS
}

\section{Gruzinov V. M.}

N. N. Zubov's State Oceanographic Institute (Moscow, Russian Federation)

Zvorykina Yu. V.

Institute of Researches and Expertise of Vnesheconombank (Moscow, Russian Federation)

Ivanov G. V.

Military Academy of the General Staff of the Armed Forces of the Russian Federation (Moscow, Russian Federation)

Sychev Yu. F.

N. N. Zubov's State Oceanographic Institute (Moscow, Russian Federation)

Tarasova O. V.

Institute of Economics and Industrial Engineering, Siberian Branch of the Russian Academy of Science (Novosibirsk, Russian Federation)

Filin B. N.

Nuclear Safety Institute of the Russian Academy of Sciences (Moscow, Russian Federation)

The article was received on November 27, 2018

\begin{abstract}
The issues of transport development of the Arctic zone of the Russian Federation (AZRF) are considered. The development of the mineral and natural resources of this zone requires the creation of a transport system with access to the main transport routes - the Northern Sea Route and the Trans-Siberian Railway. Therefore, the construction projects of the new railway routes Belkomur and the Northern Latitudinal Railway go far beyond the regional projects.

Along with projects of the Arctic ports modernization on the Northern Sea Route, the renewal of the aircraft fleet and construction of the airports and the traditional use of the internal waterways possibilities, the new trans-port system will allow increasing overall performance of the new industrial complexes created in the Arctic. This system will ensure the enterprises functioning in the eastern sector of the Russian Arctic; will allow organizing permanently the northern delivery.

The analysis of the current state of transport routes of the AZRF conducted in the article shows the main direc-tions of their development and further use.

The problem of using the possibilities of the Northern Sea Route in its eastern part to the east of the Severnaya Zemlya Islands is of particular interest. The article touches upon the perspective development of new aircraft and large icebreakers.
\end{abstract}

Keywords: The Arctic, the Northern Sea Route, Belkomur, the Northern Latitudinal Railway, the Arctic Ocean, icebreakers, tankers, oil, shelf.

\section{Information about the authors}

Gruzinov Vladimir Mikhailovich, Doctor of Geographic Sciences, Deputy Director, N. N. Zubov's State Oceanographic Institute (6, Kropotkinsky per., Moscow, Russia, 119034), e-mail: polarf@meteo.ru.

Zvorykina Yuliya Viktorovna, Doctor of Economic Sciences, Director, Institute of Researches and Expertise of Vnesheconombank (9, Akademika Sakharova Pr., Moscow, Russia, 107078.), e-mail: kpss2008@mail.ru.

Ivanov Georgiy Viktorovich, Doctor of Military Sciences, Senior Lecturer, Department of construction and application of the Navy, Military Academy of the General Staff of the Armed Forces of the Russian Federation (100, Vernadsky Pr., Moscow, Russia, 119571), e-mail: ivanoffgv@mail.ru.

Sychev Yury Fedorovich, Candidate of Physic and Mathematical Sciences, Director, N. N. Zubov's State Oceanographic Institute (6, Kropotkinsky per., Moscow, Russia, 119034), e-mail: yury.sychev@gmail.com.

Tarasova Olga Vladislavovna, Candidate of Economic Sciences, Senior Researcher, Institute of Economics and Industrial Engineering, Siberian Branch of the Russian Academy of Sciences (17, Akademika Lavrentyeva Pr., Novosibirsk, Russia, 630090), e-mail: tarasova.o.vl@gmail.com.

Filin Boris Nikolaevich, Chief Expert, Nuclear Safety Institute of the Russian Academy of Sciences (52, B. Tulskaya St., Moscow, Russia, 115191), e-mail: filin@ibrae.ac.ru.

\section{Bibliographic description}

Gruzinov V. M., Zvorykina Yu. V., Ivanov G. V., Sychev Yu. F., Tarasova O. V., Filin B. N. Arctic transport routes on land, in water and air areas. Arctic: Ecology and Economy, 2019, no. 1 (33), pp. 6-20. DOI: 10.25283/22234594-2019-1-6-20. (In Russian). 


\section{References}

1. Kryukov V. A., Kryukov Ya. V. Vzaimodeistvie severa i yuga Sibiri - v osnove "upravlenie" mul'tiplikativnymi effektami. [The interaction of the north and the south of Siberia: management of multiplicative effects]. Vestn. NGUEU, 2017, no. 4, pp. 22-27. (In Russian).

2. Klepach A. N., Razbegin V. N. Rol' transportnykh proektov v razvitii Arktiki i russkogo Severa. [Role of transport projects in the development of the Arctic and Russian North]. Gos. audit. Pravo. Ekonomika, 2017, no. 1, pp. 121-124. (In Russian).

3. O sostoyanii i problemakh zakonodatel'nogo obespecheniya realizatsii Strategii razvitiya Arkticheskoi zony Rossiiskoi Federatsii i obespecheniya natsional'noi bezopasnosti na period do 2020 goda. O sostoyanii i problemakh obespecheniya nauchnoi deyatel'nosti v Rossiiskoi Federatsii v Antarktike. Ezhegodnyi otchet (2017 god). [On the state and problems of legislative support of the implementation of the Strategy of development of the Arctic zone of the Russian Federation and ensuring national security for the period up to 2020. On the state and problems of scientific activity of the Russian Federation in Antarctica. Annual report (2017)]. Sovet po Arktike i Antarktike pri Sovete Federatsii Federal'nogo sobraniya Rossiiskoi Federatsii. Moscow, 2018. Available at: http://council.gov.ru/ media/files/DhrA9Y46BaPHLySXCkSZGZzqkIQC8jzQ. pdf. (In Russian).

4. Humpert M. The Future of the Northern Sea Route - A "Golden Waterway" or a Niche Trade Route. The Arctic Inst. September 15, 2011. Available at: http://www.thearcticinstitute.org/ the-future-of-northern-sea-route-golden/.

5. Molodichenko E. V. Proekty AO "OSK" v tselyakh obespecheniya khozyaistvennoi deyatel'nosti v Arkticheskom regione. Prezentatsiya. [Construction of the icebreaker fleet at the enterprises of JSC "USC". Presentation]. Mezhdunarodnyi forum "Sudostroenie v Arktike”, iyun', 2018, Arkhangel'sk. http://www.arcticshipbuilding.com/assets/files/Presentation/2018/1\%20 MolodichenkoEV.pdf. (In Russian).

6. Grigor'ev M. N. Potrebnosti v sudakh dlya Arktiki, potentsial rossiiskikh verfei // Mezhdunarodnyi forum “Sudostroenie v Arktike”, iyun', 2018, Arkhangel'sk. Available at: http://www.arcticshipbuilding.com/ assets/files/Presentation/2018/2\%20GrigorievMN.pdf. (In Russian).
7. Grigor'ev M. N. Razvitie arkticheskogo gruzopotoka uglevodorodnykh resursov. [The development of the Arctic cargo traffic of hydrocarbon resources]. Neftegaz. vertikal', 2017, no. 5, pp. 74-86. (In Russian). 8. Chizhkov Yu. V. Severnyi morskoi put' v strukture Arkticheskoi transportnoi sistemy. [Northern Sea Route in the structure of the Arctic transport system]. Transport Ros. Federatsii, 2017, no. 1 (68), pp. 27-32. (In Russian),

9. Kapkaikina O. A., Malov V. Yu., Tarasova O. V. Rossiiskii tranzit: otsenka perspektiv konkurentsii za evroaziatskii konteinernyi potok. [New variants of Eurasian transport corridors]. Situatsionnaya komnata kak element organizatsii ekspertnogo soobshchestva: zadachi planirovaniya i prognozirovaniya. Chapt. 2.5. Pod red. G. A. Untury; Ros. akad. nauk, Sib. otd-nie, IEOPP SO RAN. Novosibirsk, Izd-vo IEOPP SO RAN, 2018, pp. 89-102. (In Russian).

10. Kondratov N. A. Osobennosti razvitiya transportnoi infrastruktury $v$ Arkticheskoi zone Rossii. [Features of transport infrastructure development in the Arctic zone of Russia]. Geogr. vestn, 2017, no. 4 (43), pp. 68-80. DOI: 10.17072/2079-7877-20174-68-80. (In Russian).

11. Zamyatina N. Yu. Transport Severa i Arktiki: toska po malym formam. [Transport of the North and the Arctic: yearning for small forms]. Available at: https:// goarctic.ru/live/transport-severa-i-arktiki-toska-pomalym-formam//. (In Russian).

12. Bezrukov L. A. Problemy formirovaniya transportnoi sistemy Sibirskoi Arktiki. [Problems of forming the transport system of the Siberian Arctic]. EKO, 2018, vol. 48, no. 4, pp. 29-47. DOI: http://dx.doi.org/10.30680/ EC00131-7652-2018-4-29-47. (In Russian).

13. Bondarenko L. A., Ionova V. D., Malov V. Yu., Tarasova

O.V. Vozmozhnosti formirovaniya akvaterritorial'noproizvodstvennykh kompleksov (ATPK) v zone vliyaniya Severnogo morskogo puti. [Possibilities of aquaterri-torialproduction complexes (ATPC) formation in the zone of Northern sea route influence]. Aziatskaya chast' Rossii: modelirovanie ekonomicheskogo raz-vitiya $v$ kontekste opyta istorii. Otv. red. V. A. Lamin, V. Yu. Malov. Novosibirsk, Izd-vo SO RAN, 2012, pp. 219-242. (In Russian).

14. Tarasova O. V., Sokolova A. A. Perspektivy kom-pleksnogo osvoeniya Chukotskogo AO. [Prospects for the Chukotka's complex development]. Mir eko-nomiki i upravleniya, 2018 , vol. 18 , iss. 2 , pp. 69-85. DOI: 10.25205/2542-0429-2018-18-2-69-85.(In Russian)

15. Shcherbanin Yu. A. Perevozka gruzov po vnutrennim vodnym putyam Rossii: strategiya razvitiya do 2030 goda (novye vozmozhnosti dlya neftegazovogo sektora). [Transportation of goods on inland waterways of Russia. The development strategy till 2030 (new opportunities for an oil-and-gas sector)]. Nauch. tr. INP RAN, 2016, no. 1, pp. 291-301. (In Russian). 


\section{АРКТИЧЕСКИЕ ТРАНСПОРТНЫЕ МАГИСТРАЛИ НА СУШЕ, АКВАТОРИЯХ И В ВОЗДУШНОМ ПРОСТРАНСТВЕ}

\section{В. М. Грузинов}

Государственный океанографический институт им. Н. Н. Зубова (Москва, Российская Федерация)

\section{Ю. В. Зворыкина}

Институт исследований и экспертизы Внешэкономбанка (Москва, Российская Федерация)

\section{Г. В. Иванов}

Военная академия Генерального штаба Вооруженных сил Российской Федерации

(Москва, Российская Федерация)

\section{Ю. Ф. Сычев}

Государственный океанографический институт им. Н. Н. Зубова (Москва, Российская Федерация)

\section{О. В. Тарасова}

Институт экономики и организации промышленного производства Сибирского отделения РАН

(Новосибирск, Российская Федерация)

\section{Б. Н. Филин}

Институт проблем безопасного развития атомной энергетики РАН (Москва, Российская Федерация)

Статья поступила в редакцию 27 ноября 2018 г.

Рассмотрены вопросы транспортного развития Арктической зоны Российской Федерации (АЗРФ). Освоение ее минерально-сырьевых природных ресурсов требует создания транспортной системы, имеющей выход на основные магистрали - Северный морской путь (СМП) и Транссибирскую железную дорогу. Поэтому проекты строительства новых железнодорожных маршрутов Белкомур и Северный широтный ход выходят далеко за региональные рамки. В соединении с проектами модернизации арктических портов на трассе СМП, обновления парка воздушных судов и строительства аэропортов, традиционного использования возможностей внутренних водных путей новая транспортная система даст возможность увеличить эффективность работы новых промышленных комплексов. Она позволит обеспечить работу предприятий восточного сектора российской Арктики, организовать на постоянной основе северный завоз.

Приведенный в статье анализ современного состояния транспортных магистралей АЗРФ показывает основные направления их развития и дальнейшего использования. Особый интерес представляет проблема использования возможностей СМП в его восточной части - к востоку от островов архипелага Северная Земля. Затронуты вопросы перспективного создания новых воздушных судов и крупных ледоколов.

Ключевые слова: Арктика, Северный морской путь, Белкомур, Северный широтный ход, Северный Ледовитый океан, ледоколы, танкеры, нефть, шельф.

(ㄷ Грузинов В. М., Зворыкина Ю. В., Иванов Г. В., Сычев Ю. Ф., Тарасова О. В., Филин Б. Н., 2019 


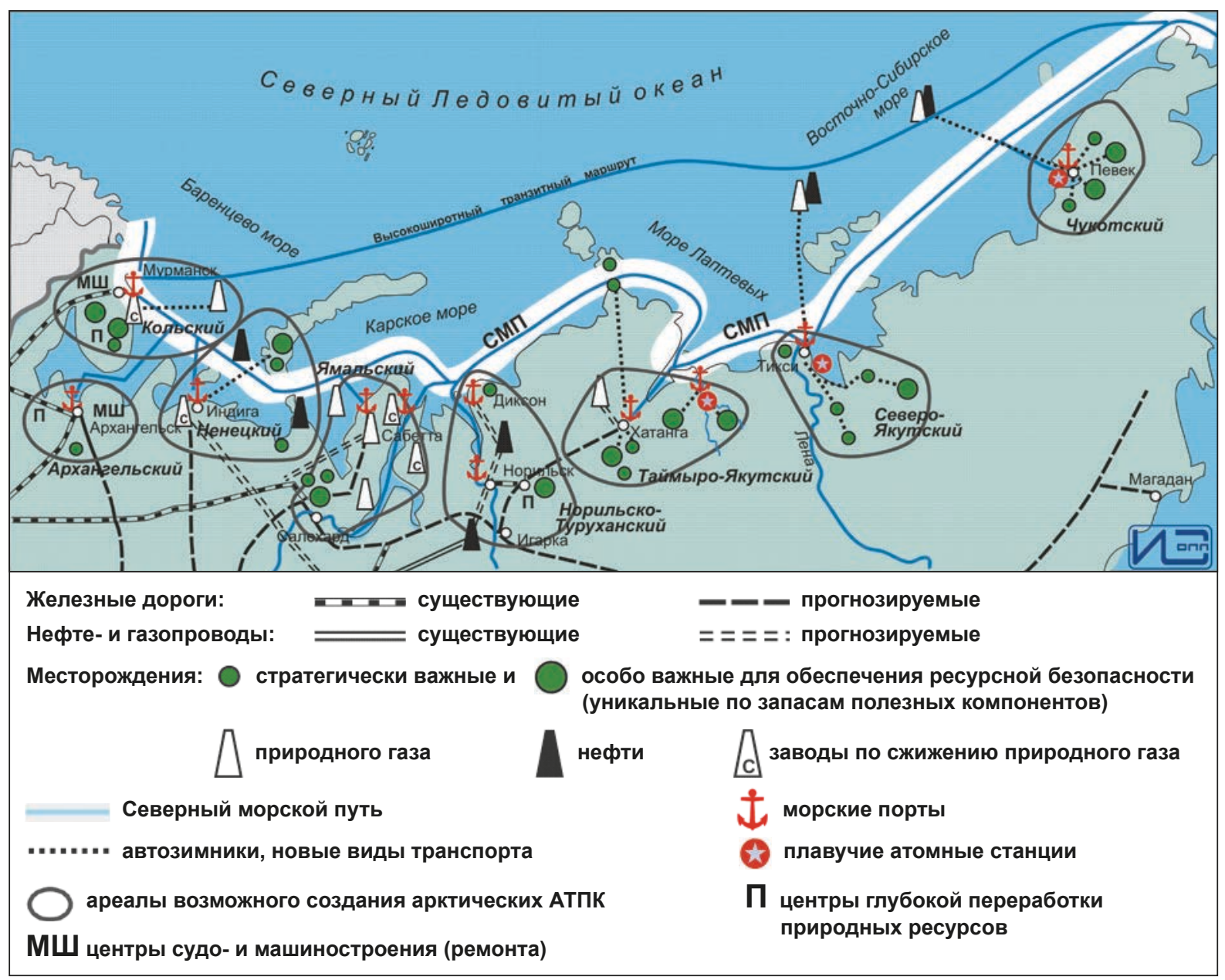

Рис. 1. Обзорная схема прогнозируемых арктических акватерриториальных производственных комплексов (АТПК) Fig. 1. Overview of the projected Arctic aqua-territorial production complexes (ATPC)

\section{Введение}

Для выполнения задач широкомасштабного освоения и развития Арктической зоны Российской Федерации (АЗРФ) в первую очередь с учетом того, что Восточная Сибирь и побережье Северного Ледовитого океана (СЛО) являются территорией с малоразвитой транспортной инфраструктурой, необходимо создать эффективно функционирующую арктическую транспортную систему на базе существующих и вновь построенных транспортных магистралей. Поэтому интенсификация освоения этих пространств сопряжена с колоссальными затратами, а с учетом демографической ситуации в стране - и со сложностью набора рабочей силы.

Так как арктическая транспортная система является неотъемлемой частью транспортной системы России, вопросу развития и эксплуатации транспорта в Арктике руководство страны уделяет повышенное внимание 1 .

1 Портал государственных программ Российской Федерации, направление «Инновационное развитие и модернизация экономики». - URL: https://programs.gov.ru/Portal/.
Схема на рис. 1 дает представление о планах развития системы территориальных производственных комплексов Арктической зоны. Освоение ряда крупных и уникальных месторождений цветных металлов, природного газа и нефти на территории АЗРФ и в акватории СЛО в перспективе даст значительный прирост валового регионального продукта арктических субъектов Федерации и способно создать большой мультипликативный эффект в экономике страны [1].

В отличие от предложенной в государственной программе «Социально-экономическое развитие Арктической зоны Российской Федерации» концепции создания опорных зон экономического развития АЗРФ контуры перспективных АТПК на рис. 1 очерчены с учетом более долгосрочного прогноза, т. е. с включением дополнительных взаимосвязей между ресурсными и инфраструктурными проектами на перспективу до 2035 г. В то же время неоспоримым является упор на очаговое освоение арктических территорий.

С учетом особенностей и специфики АЗРФ, связанных с суровыми климатическими условиями и боль- 
шими неосвоенными пространствами, можно выделить следующие основные направления развития ее транспортной системы на ближайшую перспективу:

1. Интеграция транспортной сети АЗРФ в транспортную систему страны в целом путем соединения материковой и портовой инфраструктуры в единую логистическую систему. Создание единой логистической системы базируется на следующих ключевых проектах транспортной инфраструктуры материковой части АЗРФ, правильное сочетание которых в пространстве и времени должно обеспечить новое качество логистики: Белкомур, Северный широтный ход (СШХ), Бованенково - Сабетта, Баренцкомур, Карскомур, Мурманский транспортный узел, глубоководный порт Архангельск, порт Индига. Растет грузопоток по Северному морскому пути (СМП).

2. Развитие СМП, обеспечение его бесперебойного круглогодичного функционирования и создание современной портовой инфраструктуры на всем маршруте следования судов. Круглогодичное функционирование СМП (в восточной его части) возможно только при модернизации ледокольного флота России, в первую очередь атомного.

3. Модернизация и расширение состава транспортных средств в «северном, арктическом исполнении», включая морские и речные суда, автомобильный транспорт высокой проходимости, воздушные суда для региональной авиации.

4. Социально-экономическое развитие Арктики невозможно без решения социальных вопросов для жителей арктических субъектов Федерации и обеспечения транспортной доступности на тех территориях, где проживают и работают они и члены их семей.

Целью этой статьи является описание состояния и возможностей основных транспортных маршрутов в Арктике, хода реализации проектов развития транспортной сети и заострение внимания на проблемах, решение которых позволит улучшить обеспечение транспортной доступности арктических территорий с учетом тенденций развития мировой экономики и возможных климатических изменений в арктическом регионе.

\section{Структуры развития транспорта в АЗРФ}

Развитие транспорта в АЗРФ - межведомственная и макрорегиональная задача, требующая координации усилий многих участников, в том числе крупного бизнеса.

Отдельного внимания заслуживает распределение полномочий между органами государственной власти и корпорациями по различным направлениям арктической политики. В декабре 2017 г. решением Правительства РФ госкорпорации «Росатом» были переданы функции по осуществлению контроля судоходства в зоне СМП. Под управлением «Росатома» действует ФГУП «Атомфлот», обслуживающее атомный ледокольный флот России. Президент России подписал федеральный закон «О внесении измене- ний в отдельные законодательные акты Российской Федерации» от 27 декабря 2018 г. № 525-Ф3, определяющий полномочия «Росатома» как единого оператора в сфере развития и функционирования СМП и прилегающих территорий. В ведении Минтранса России и ОАО «РЖД» находится строительство железнодорожной инфраструктуры, в том числе ключевых проектов - Северного широтного хода и Мурманского транспортного узла. Вопросами экологического надзора и контроля за выдачей лицензий в ресурсном секторе занимается Минприроды России. Над добычей ресурсов в АЗРФ и их транспортировкой работают корпорации «НОВАТЭК», «Газпром», «Роснефть», «Газпромнефть», «ЛУКОЙЛ», «Востокуголь», «Норникель». Министерство обороны России осуществляет контроль над стратегическими объектами, расположенными в АЗРФ, в том числе над аэродромами двойного назначения.

Для координации усилий всех заинтересованных сторон в развитии арктического транспорта распоряжением Минтранса России в июне 2015 г. в составе Государственной комиссии по вопросам развития Арктики была образована рабочая группа «Развитие транспортной системы». В повестке дня ее работы проблемы развития инфраструктуры, производство транспортных средств, развитие систем связи и технологий перевозки, обеспечение безопасной работы транспорта в Арктике.

Не можем не привести цитату из [2]: «Транспортные проекты в Арктике - это больше чем транспортные проекты, поскольку они направлены на переструктурирование пространства, переоткрытие северных территорий для хозяйственного освоения и создания новой среды обитания, исконной для русского народа». И далее авторы абсолютно справедливо считают, что «...как бы жестко ни стояли бюджетные ограничения и для государства, и для корпораций, без масштабных прорывных проектов не будет мощного взлета в развитии России. Система государственных стратегических программ должна быть подкреплена пакетом проектов, имеющих стратегический национальный характер, которые должны утверждаться на уровне Правительства и иметь свою особую систему управления» [2].

\section{Развитие морской и железнодорожной инфраструктур АЗРФ}

Транспортные перевозки в арктических районах осуществляются автомобильным, воздушным, железнодорожным и водным видами транспорта. Ключевое значение для развития российской Арктики в современной геополитической ситуации имеет обеспечение интересов России на морских маршрутах, но эти маршруты должны иметь эффективное сопряжение на побережье с маршрутами других видов транспорта. В части развития железнодорожной инфраструктуры арктических регионов, являющейся важнейшей составляющей общей системы связан- 


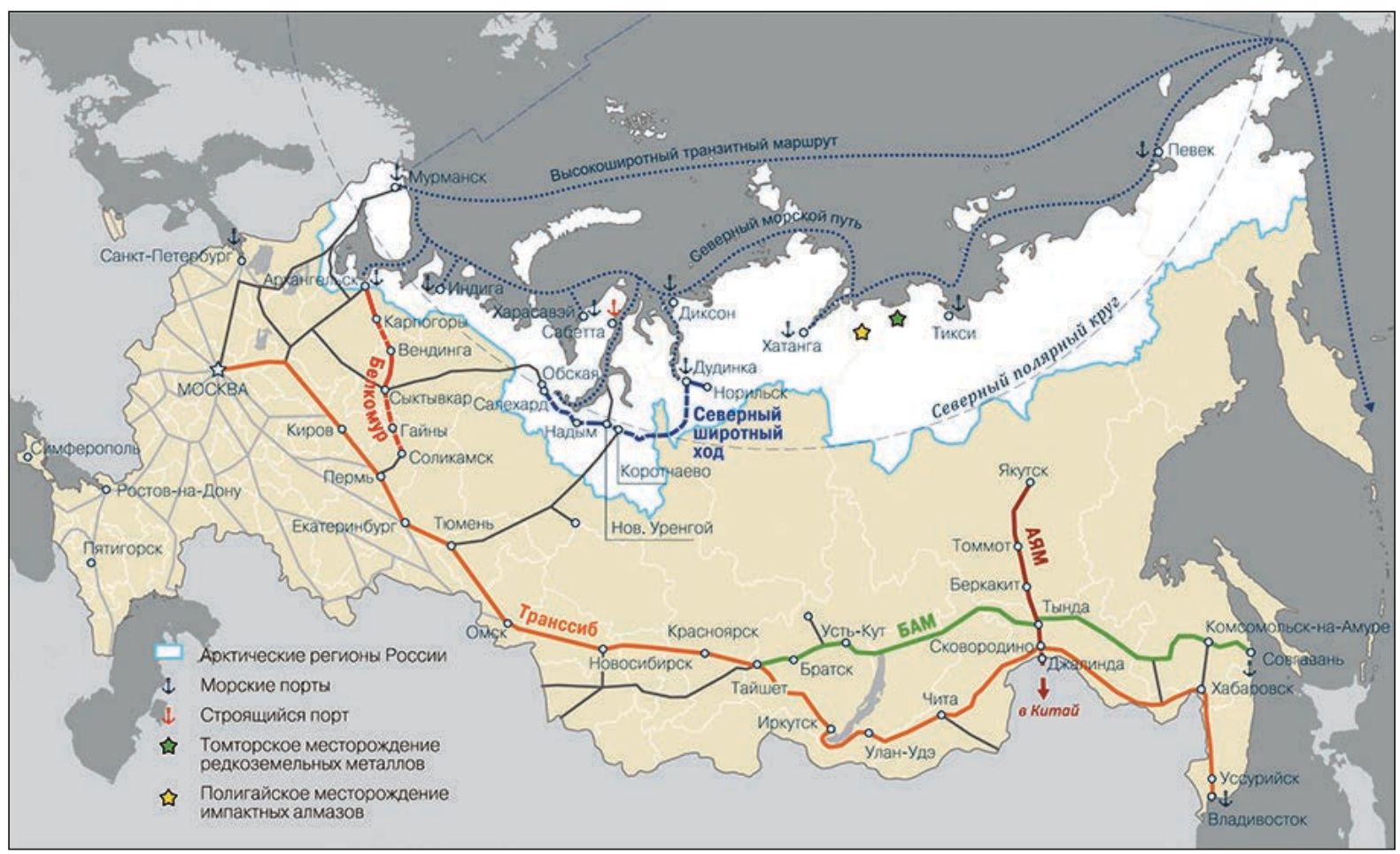

Рис. 2. Развитие железнодорожной и морской инфраструктур Арктики и Сибири. Источник: http://pro-arctic.ru/wp-content/ uploads/2016/07/kyav.png

Fig. 2. The development of rail and maritime infrastructures in the Arctic and Siberia. Available at: http://pro-arctic.ru/wp-content/ uploads/2016/07/kyav.png

ности северных российских территорий с остальной территорией страны, необходимо отметить ряд проектов (рис. 2).

\section{Белкомур}

Решением трех субъектов Федерации (Республики Коми, Архангельской области и Пермского края) в 1996 г. в Сыктывкаре была учреждена Межрегиональная акционерная компания «Белкомур» (Белое море - Коми - Урал). По ее инициативе прорабатывается возможность реализации проекта Белкомур - строительства железнодорожной магистрали Архангельск - Сыктывкар - Соликамск (Пермь), который предусматривает обеспечение сквозного железнодорожного сообщения по маршруту Архангельск - Сыктывкар - Пермь (Соликамск) протяженностью 1161 км, а также к промышленно развитому Уралу и морским портам Северо-Запада и АЗРФ.

Большой интерес к проекту проявил Китай, который находит новые рынки сбыта своих товаров, в том числе и в Северной Европе. Однако торговый экспорт Китая существенно сдерживается отсутствием современных торговых путей.

Крупнейшая китайская корпорация «Поли Технолоджи» в сентябре 2015 г. подписала соглашение с компанией «Белкомур» о совместной реализации строительства этой железной дороги. Китайская сторона видит в проекте дополнительный выход к СМП. Безусловно, он выгоден и для нашей страны.
Максимальная мощность Белкомура может составить 35 млн т грузов в год. По некоторым данным, возрастет валовый региональный продукт трех северных субъектов Федерации, будет создано около 40 новых предприятий, существенно увеличится ресурсный потенциал северных регионов. По имеющимся данным, новая железная дорога позволит доставлять из регионов различное сырье: до 5 млн м³ леса из Архангельской области, 7 млн м ${ }^{3}$ леса из Республики Коми, а также горючие сланцы, титан, бокситы. Пермский край сможет организовать вывоз калийных удобрений.

Одним из решающих моментов этого проекта является строительство глубоководного порта Архангельска. С учетом тяжелой ледовой обстановки, мелководья, неудобной береговой линии строительство такого порта по некоторым оценкам будет стоить больше, чем сам Белкомур.

По мнению экспертов, новый Архангельский порт должен будет удовлетворять следующим характеристикам:

- ежегодный грузооборот должен составлять 30 млн т;

- нужно обеспечить примерно 9 тыс. рабочих мест в порту и на припортовых предприятиях;

- возможность принимать суда дедвейтом до 70-80 тыс. т.

Не останавливаясь подробно на финансовых вопросах, отметим, что сейчас рассматривается не- 
сколько вариантов финансирования проекта: государственно-частное партнерство (ГЧП), привлечение РЖД и некоторые другие.

Однако Белкомур имеет весьма большое экономическое и политическое значение, которое окупит все затраты на его создание. Он свяжет 12 регионов Северо-Запада и 9 регионов Урала, дающих до 80\% валютных поступлений в бюджет страны, обеспечит поставку на уральские заводы дешевой нефти, газа, бокситов, угля, леса и других ресурсов, которые позволят производить и продавать конкурентоспособную продукцию [2].

\section{Северный широтный ход}

В рамках совершенствования железнодорожной инфраструктуры российской Арктики реализуется проект «Создание железнодорожного Северного широтного хода», которым предусмотрено соединение Северной и Свердловской железных дорог, сокращение транспортных коммуникаций от месторождений в северных районах Западной Сибири до портов Балтийского бассейна. Проект имеет большое значение для развития транспортной инфраструктуры Ямало-Ненецкого автономного округа и АЗРФ.

В сентябре 2018 г. после более чем двухлетнего обсуждения между Росжелдором и специально созданной под проект компанией «СШХ» подписана концессия на Северный широтный ход. Организатором финансирования железнодорожного мегапроекта может стать ВТБ.

Идее строительства дороги на севере Западной Сибири насчитывается более 50 лет. Работа над проектом возобновилась в 2006 г., а новую жизнь он получил в марте 2017 г., когда РЖД и «Газпром» подписали соглашение о его совместной реализации. Проект предполагает строительство моста через Обь с железнодорожными подходами, железнодорожной линии Салехард - Надым и моста через Надым. Концессионер же должен обеспечить финансирование, строительство и эксплуатацию линии Обская - Салехард - Надым. Согласно обоснованию инвестиций общая протяженность дороги по концессии - 353 км, ее стоимость 113 млрд руб., из них 50 млрд руб. пойдет на строительство моста, 61 млрд руб. - железнодорожной линии, а почти 2 млрд руб. - моста через Надым. Вся дорога с учетом строительства и реконструкции смежных участков предварительно оценивается в 236,7 млрд руб.

На государственную концессионную часть проекта выделят 12,7 млрд руб. в виде капитального гранта, еще около 97,2 млрд руб. инвесторы предполагали взять в кредит. 18,4 млрд руб. приходится на корпоративное финансирование, сами же акционеры внесут в проект капитал на 1,8 млрд руб. Если во время проектирования смета проекта увеличится более чем на 10\%, этот риск инвестор разделит с государством.
Участок железной дороги Бованенково - Сабетта

Этот участок станет заключительным звеном в проекте СШХ с выходом на Северный морской путь. Однопутную железную дорогу протяженностью 170 км планируется использовать для промышленных перевозок грузов нефтегазовых компаний. Запланированы следующие объемы: на пятый год эксплуатации - 7 млн т, на десятый год - 14 млн т.

Строительство ведется в рамках государственночастного партнерства «ВИС ТрансСтрой», которое обязуется за счет собственных и заемных средств провести весь комплекс работ и завершить строительство линии до конца 2019 г. Объем инвестиций превышает 113 млрд руб. Реализация проекта будет способствовать освоению минерально-сырьевой базы всей Западной Сибири и Арктики, а также развитию транспортной инфраструктуры Ямала.

\section{Баренцкомур}

Баренцкомур (Баренцево море - Коми Урал) - проект железнодорожной магистрали, которая должна соединить Индигу, Сосногорск и Троицко-Печорск в Республике Коми с поселком Полуночное в Свердловской области и городом Сургут в Ханты-Мансийском автономном округе. Общая протяженность участка Индига - Ивдель (Полуночное) составит около 1200 км. Этот проект внесен в «Стратегию развития железнодорожного транспорта в Российской Федерации до 2030 года». Предполагается, что строительство Баренцкомура (отдельно от Белкомура или вместе с ним) позволит перенаправить экспортные грузы с Урала и Западной Сибири в порт Индига вместо портов Украины и Прибалтики [3].

Планируемый морской порт в незамерзающей губе Индига (проектная стоимость строительства порядка 353 млрд руб.) в юго-восточной части Баренцева моря сможет принимать крупнотоннажные суда дедвейтом от 150 до 300 тыс. т. Строительство в Индиге стационарного нефтяного терминала позволит ежегодно отгружать на экспорт до 30 млн т нефти. Потенциальная грузообразующая база района тяготения к порту Индига может составить до 120 млн т в 2030 г.

\section{Карскомур}

Карскомур - проект железнодорожной магистрали Воркута - Усть-Кара (поселок на территории Ненецкого автономного округа) протяженностью 200 км соединяет Урал с Карским морем и предполагает создание порта в поселке Усть-Кара. Железная дорога Воркута - Усть-Кара может понадобиться для вывоза ресурсов с северных участков Печорского угольного бассейна, которые еще не дождались разработки. Об этом сказано в «Стратегии развития Арктической зоны Российской Федерации и обеспечения национальной безопасности на период до 2020 года». 
Арктические порты

K числу основных арктических портов относятся: Мурманск, Нарьян-Мар, Варандей (Баренцево море), Архангельск, Мезень, Онега, Витино, Кандалакша (Белое море), Диксон, Дудинка, Сабетта (Kapское море), Тикси, Хатанга (море Лаптевых), Певек (Восточно-Сибирское море), Эгвекинот, Беринговский, Провидения, Анадырь (Берингово море).

Практически все арктические порты (за исключением Дудинки) требуют реконструкции, ремонта, оснащения новой техникой и выполнения дноуглубительных работ.

По данным Росморречфлота, по итогам 2017 г. грузооборот порта Мурманск составил 51,67 млн т (рост по сравнению с прошлым годом на 54,5\%), порт Варандей увеличил перевалку грузов на 3,4\%, до 8,28 млн т. Грузооборот порта Сабетта составил 7,99 млн т (рост в 2,8 раза), Архангельска 2,4 млн т (-8\%), Дудинки - 1,24 млн т (+3,7\%), Кандалакши - 1,63 млн т (рост в 2 раза). Прочими портами бассейна перевалено 1 млн т. На долю порта Мурманск пришлось 70\% совокупного грузооборота бассейна, Варандея - 11,2\%, Сабетты - 10,8\%.

Между тем ранее проведенный экспертный анализ существующей и перспективной (на период до 2030 г.) грузовой базы для транспортировки в рамках СМП и ключевых конкурирующих маршрутов свидетельствовал о потенциале роста грузопотока в указанный период до 104,4 млн т (на основе данных компаний о потенциале формирования грузовой базы), а по данным фонда «Центр стратегических разработок» - до 80 млн т.

Свой интерес к развитию производственного комплекса Арктики в различный период подтверждали «АЛРОСА», «Востокуголь», «Газпром», ГЛОНАСС, «НОВАТЭК», «Норникель», РЖД, «Росатом», «Роснефть», «Роскосмос», «Транснефть».

Наибольший вклад могут внести нефть и конденсат (до 36,7 млн т - при реализации проектов «Приразломная», «Новый порт» и «Долгинского» (Восток) компанией «Газпромнефть», «Варандей» компанией ЛУкОЙЛ, СПГ (до 32,7 млн т при реализации проектов «Ямал СПГ» и «Арктик СПГ» компанией «НОВАТЭК», «Печора СПГ» компанией «Роснефть»). Как минимум 1 млн т может составить вклад перевозок руд (концентратов), прежде всего компанией «Норильский никель». 30 млн т может составить вклад угля («Тайбасс», Востокуголь). В 2 млн т можно оценить потенциал грузоперевозок продукции и материалов в рамках северного завоза.

Рост грузооборота арктических портов требует совершенствования и увеличения пропускной способности железнодорожной сети.

Учитывая сказанное, авторы полагают, что большую роль в становлении новой транспортной системы российской Арктики может и должно сыграть государственно-частное партнерство. Каждый порт, каждый участок дороги, пополнение флота могут быть объектами ГЧП соглашений в соответствии с федеральным законом «О государственно-част- ном партнерстве, муниципально-частном партнерстве в Российской Федерации и внесении изменений в отдельные законодательные акты Российской Федерации» от 13 июля 2015 г. № 224². Однако готовность к реализации проектов ГЧП в арктических регионах в основном низка.

Еще сложнее дело может обстоять со сквозными проектами, затрагивающими интересы регионов, имеющих на текущий момент совершенно различный уровень ГЧП практик. В табл. 1 показаны оценки уровня развития ГЧП в регионах расположения того или иного проекта в соответствие с рейтингом за 2017-2018 гг.3 По каждому проекту рассчитаны средний процент и условное место мезорегиона в системе ГЧП Российской Федерации.

Обобщенная готовность регионов, задействованных в проекте Северный широтный ход, наивысшая - 64\%. Второе место в сводном рейтинге арктических транспортных коридоров занимает проект магистрали Белкомур, включающий ввод железнодорожных линий Соликамск - Гайны Сыктывкар и Вендинга - Карпогоры, реконструкцию существующих участков дороги на территориях четырех субъектов Федерации, а также расширение порта Архангельск.

\section{Развитие морских перевозок по \\ Северному морскому пути}

Арктический бассейн - район быстрого роста морских перевозок, где важную роль играет СМП. В структуре экспорта преобладают углеводороды, уголь, лес, нефтепродукты, руды цветных металлов, оборудование, в структуре импорта - продовольствие.

Большое значение для развития перевозок в Арктике имеют изменения климата. Климатообразующая роль Арктики, происходящие в этом регионе изменения природных условий не только оказывают влияние на арктические транспортные потоки, но и могут вызвать в долгосрочной перспективе глобальную перестройку товаропотоков.

В результате потепления климата все большая часть Северного Ледовитого океана летом освобождается от ледяного покрова. Его акватории становятся более доступными для судоходства, разведки и разработки минеральных ресурсов, рыбного промысла, что открывает дополнительные возможности для развития транспорта, в том числе с привлечением частных инвесторов.

Освоение Арктики при условии обеспечения ледокольной проводки и создания обеспечивающей инфраструктуры может создать возможность круглогодичной транспортировки грузов между Европой и Юго-Восточной Азией по СМП вдоль россий-

\footnotetext{
2 http://www.consultant.ru/cons/cgi/online.cgi?req=doc \& base $=$ LAW \& $n=303642 \&$ fld $=134 \& d s t=1000000001,0 \& r$ nd=0.5222761785377004\#030998677219491944.

3 Рейтинг регионов России по уровню развития ГЧП (2018). URL: http://www.pppi.ru/regions.
} 
Таблица 1. Ключевые транспортные проекты Арктики в зеркале рейтинга ГЧП

\begin{tabular}{|c|c|c|c|c|c|}
\hline Субъект Федерации & $\begin{array}{c}\text { Уровень } \\
\text { развития } \\
\text { ГЧП, \% }\end{array}$ & $\begin{array}{c}\text { Занимаемое } \\
\text { место }\end{array}$ & Субъект Федерации & $\begin{array}{c}\text { Уровень } \\
\text { развития } \\
\text { ГЧП, \% }\end{array}$ & $\begin{array}{c}\text { Занимаемое } \\
\text { место }\end{array}$ \\
\hline \multicolumn{3}{|c|}{ Белкомур } & \multicolumn{3}{|c|}{ Севсиб + Баренцкомур } \\
\hline Архангельская область & 51,2 & 31 & Республика Коми & 29,2 & 56 \\
\hline Республика Коми & 29,2 & 56 & Свердловская область & 76,9 & 10 \\
\hline Пермский край & 80,6 & 6 & Ханты-Мансийский АО & 66,5 & 18 \\
\hline Свердловская область & 76,9 & 10 & Томская область & 24,6 & 65 \\
\hline \multirow[t]{3}{*}{ Итог всего проекта } & 59,0 & 26 & Красноярский край & 75,4 & 11 \\
\hline & & & Иркутская область & 63,7 & 19 \\
\hline & & & Итог всего проекта & 56,0 & 30 \\
\hline \multicolumn{3}{|c|}{ Северный морской путь } & \multicolumn{3}{|c|}{ Енисейский меридиан } \\
\hline Мурманская область & 39,0 & 46 & Красноярский край & 75,4 & 11 \\
\hline $\begin{array}{l}\text { Архангельская } \\
\text { область }\end{array}$ & 51,2 & 31 & Республика Хакасия & 17,6 & 77 \\
\hline Ненецкий АO & 22,5 & 69 & Республика Тыва & 13,1 & 80 \\
\hline Ямало-Ненецкий АО & 51,7 & 29 & Итог всего проекта & 35,0 & 56 \\
\hline Красноярский край & 75,4 & 11 & \multicolumn{3}{|c|}{ Северный широтный ход } \\
\hline $\begin{array}{l}\text { Республика Саха } \\
\text { (Якутия) }\end{array}$ & 66,6 & 17 & Ямало-Ненецкий АО & 51,7 & 29 \\
\hline Чукотский АО & 28,0 & 59 & Красноярский край & 75,4 & 11 \\
\hline Итог всего проекта & 48,0 & 37 & Итог всего проекта & 64,0 & 20 \\
\hline
\end{tabular}

ского побережья СЛО, что на треть короче южного маршрута (через Индийский океан и Суэцкий канал), а экономия времени прохождения судов составляет порядка 20 суток (таким образом, для судна с суточными затратами 50-60 т топлива при цене 600700 долл. экономия при использовании СМП может составить около 600 тыс. долл. за рейс).

За последнее десятилетие Азия обогнала Северную Америку как крупнейший рынок европейского экспорта, а прогноз на удвоение мировой торговли к 2020 г. еще больше повысит важность судоходных путей, функционирующих на принципах линейного судоходства по регулярному графику и утвержденному маршруту. В общей сложности более 6 тыс. судов, большинство которых являются контейнеровозами, включены в эту систему [4]. До настоящего времени на арктических маршрутах линейное судоходство не используется.

Сейчас на западном участке СМП осуществляется круглогодичная навигация по маршруту Мурманск - Дудинка для обеспечения деятельности Норильского горно-металлургического комбината, начата транспортировка нефти из районов Обской губы, Варандея и Колгуева. В связи с освоением арктических месторождений крупнейшие российские нефтегазовые и судоходные компании организовали интенсивное строительство арктического транспортного флота. Это танкеры класса Arc7 для обеспечения круглогодичного вывоза нефти Новопортовского месторождения, а также круглогодичной самостоятельной транспортировки газового конденсата в рамках проекта «Ямал СПГ», ледокольные суда снабжения добывающих платформ («Геннадий Невельской»), ледокольные суда обеспечения («Александр Санников»), самые мощные в мире дизельные ледоколы «Владивосток», «Новороссийск», «Мурманск» [5].

На восточном участке СМП внутренний грузопоток, основу которого составляют нефть, газоконденсат и лесные грузы, вероятно, мог быть достаточным для рентабельной работы трассы. Однако, к сожалению, этого пока не произошло. Но вместе с тем прогнозируемое увеличение спроса на СПГ и увеличение скорости доставки при использовании 
СМП, особенно в условиях долгосрочных контрактов, позволит поднять рентабельность СМП. В этом случае необходимо будет обеспечение круглогодичной работы восточного участка СМП, для чего строятся универсальные атомные ледоколы («Арктика», «Сибирь», «Урал»), но с учетом развития грузопотока свыше 40 млн т в восточном секторе Арктики требуется принятие решения о строительстве еще двух таких атомных ледоколов и начале строительства линейного атомного ледокола-лидера мощностью 170 МВт [6; 7].

По мнению Росатома, решение о строительстве серийных атомных ледоколов «Лидер» целесообразно принимать после получения официального прогноза о достижении грузопотоком в восточной части Северного морского пути объемов 30-40 млн т в год. При этом решение о строительстве должно быть принято за семь лет до достижения таких объемов.

Годовые плановые объемы грузопотоков по Северному морскому пути, установленные «Комплексным планом модернизации и расширения магистральной инфраструктуры» (распоряжение Правительства РФ от 30 сентября 2018 г. № 2101-р), таковы: в 2018 г. - 9,9 млн т, в 2019 г. - 26, в 2020 г. 41, в 2021 г. - 51, в 2022 г. - 61, в 2023 г. - 71, в 2024 г. - 80 млн т.

K сожалению, пока отсутствует увязка воедино всех необходимых мероприятий по достижению ежегодных показателей перевозки грузов по Северному морскому пути, включая номенклатуру и ежегодный объем грузов, планы компаний-отправителей и меры государственной поддержки по реализации их проектов.

Важно отметить, что на 1 декабря 2018 г. объем перевозок по СМП составил 17,8 млн т. Показатель 2018 г. выполнен на 180\%. Транзитные перевозки составили 0,5 млн т. Из этого следует, что как плановые, так и сверхплановые перевозки были осуществлены в западной части Северного морского пути.

С самого начала работы СМП всегда подчеркивалось, что он значительно короче, чем плавание через Суэцкий канал. Расстояние на маршруте Роттердам - Шанхай через Суэцкий канал составляет 10590 миль, в то время как по СМП - 8900 миль. Именно на этом строилась экономическая логика выгодного использования Северного морского пути. Кроме того, следует отметить, что СМП соединяет устья судоходных сибирских рек, объединяя их в единую транспортную систему. Можно подчеркнуть, что к востоку от Урала внутренний водный транспорт является единственным безальтернативным видом транспорта.

Безальтернативность для нашей страны использования Северного морского пути и других видов внутреннего водного транспорта для обеспечения хозяйственной деятельности остается очень большой проблемой. Очевидно, что потребуются более значительные средства для организации бесперебойного транспортного обеспечения восточной части АЗРФ. К сожалению, как уже неоднократно отмечалось, из-за санкций и падения цен на нефть доходная часть бюджета сократилась, и планируемые расходы, вероятно, будут иметь другие показатели. В связи с этим скорее всего будут сдвинуты и временные рамки важнейших транспортных проектов, в том числе и водных.

Вместе с тем в ряде работ показано, что перевозка грузов по Северному морскому пути гораздо дороже, чем через Суэцкий канал. Кроме того, перспективы использования СМП для транзитных перевозок грузов также остаются не вполне ясными. Тем более что вместе с оплатой ледоколов происходит удорожание перевозок по трассе СМП [4; 8].

По мнению А. Н. Пилясова, СМП не станет конкурентом Суэцкого канала, а может лишь принять на себя часть объемов грузоперевозки во время пиковой загрузки канала, но для внутренних перевозок России СМП играет, несомненно, важную хозяйственную роль.

Расчеты новосибирской группы ученых [9] с использованием транспортной модели дали аналогичный вывод: в интервале наиболее вероятных тарифов на перегрузку в новых портах и на перевозку по новым участкам железных дорог в перспективе Россия получит лишь небольшую часть евроазиатского транзита. При этом запас конкурентоспособности у суэцкого маршрута достаточно внушителен: при развитии новых евроазиатских транспортных коридоров он может легко восстановить конкурентные преимущества путем незначительного снижения тарифа на перевозку (до 2\%).

Безопасное плавание по СМП требует развития различных видов обеспечения морской деятельности. Для решения задач поисково-спасательного обеспечения в арктическом и дальневосточном регионах для ФГБУ «Морспасслужба» построено семь современных многофункциональных аварийно-спасательных судов ледовых классов Icebreaker6 и Агс5.

Навигационно-гидрографическое обеспечение в акватории СМП осуществляет ФГУП «Гидрографическое предприятие», которое выполняет целевое гидрографическое изучение наиболее важных существующих и вновь создаваемых судоходных районов и трасс СМП, обслуживает средства навигационного оборудования и организовало работу по обеспечению мореплавателей информацией о безопасности на море в прибрежных районах «Запад» и «Восток» акватории СМП.

\section{Сухопутный транспорт}

Одну из основных нагрузок по транспортировке грузов в сухопутной части Арктики несет трубопроводный транспорт, являющийся основным при перевозке углеводородов.

K числу проектов, реализуемых на арктических территориях, относятся строительство нефтепровода Пурпе - Самотлор (488 км) пропускной способ- 
ностью 45 млн т в год нефти от Ванкорского месторождения Красноярского края с поставкой ее в трубопроводную систему Восточная Сибирь - Тихий океан и далее на экспорт. Новые центры газодобычи и газотранспортную систему на полуострове Ямал создают «Газпром» и «Транснефть». Здесь строятся трубопроводы протяженностью свыше 2100 км Бованеково - Ухта и Бованенково - Ухта-2. К 2030 г. планируется ввести в эксплуатацию газопроводы от месторождений Обской и Тазовской губ [10].

Автодорожная сеть в российской Арктике характеризуется неравномерным развитием. Имеются субъекты, у которых отсутствует круглогодичный выход на автодорожную сеть России (Ненецкий автономный округ). Для связи с Республикой Коми в зимний период от Нарьян-Мара до Усинска ежегодно строится временная автомобильная дорога, так называемый зимник, протяженностью свыше 70 км. Нужно отметить, что распоряжениями Правительства РФ предусмотрено предоставление в 2018 г. бюджету Ненецкого автономного округа 404,4 млн руб. на продолжение строительства участков автомобильной дороги общего пользования регионального значения Нарьян-Мар - Усинск.

Среди территорий АЗРФ относительно благоприятная ситуация характерна для субъектов западного сектора российской Арктики [10]. Всего по территории Арктической зоны проходят участки автомобильных дорог федерального значения общей протяженностью 729,5 км, на них проводится планомерная ремонтно-восстановительная работа. Так, в 2017 г. субъектам Федерации, находящимся на территории АЗРФ, были предоставлены средства федерального бюджета в виде межбюджетных трансфертов на достижение целевых показателей региональных программ в сфере дорожного хозяйства.

Сложные природные условия территории Арктики приводят к повышению трудоемкости строительства дорог в 2-2,5 раза по сравнению с континентальными технологиями, к удлинению сроков строительства втрое [3].

Для обеспечения транспортной доступности арктических территорий необходимо создать вездеходную технику для строительства объектов различного назначения и удовлетворения социально-экономических потребностей людей, проживающих на этих территориях [11].

\section{Внутренние водные пути}

Внутренний водный транспорт играет важную роль в транспортной обеспеченности арктических территорий. Однако сейчас имеются значительные проблемы, препятствующие его полноценному использованию. $\mathrm{K}$ этому надо добавить, что недостаточное финансирование ведет к ухудшению состояния водных путей, снижает их доступность на территориях со слаборазвитым сухопутным сообщением.
K сожалению, внутренним водным путям присущи значительные недостатки. Прежде всего это сезонность работы. Зимой реки замерзают, и даже серьезное потепление, которое сейчас отмечается в Арктике, не приводит к существенному увеличению сроков их возможного использования. Другие ограничения связаны с их мелководностью, снижением протяженности. Эта проблема усугубляется маловодностью ряда рек. В таких условиях более половины судов не могут ходить с полной загрузкой, что ведет к увеличению числа убыточных рейсов.

Около 80\% водных путей России являются единственной возможностью доставки грузов и обеспечения северного завоза. В частности, в Якутии в связи с отсутствием железных и автомобильных дорог внутренний водный транспорт является безальтернативным видом сообщения.

Наличие искусственных водных систем на европейской части страны (Волго-Балтийской, Беломоро-Балтийской) и водохранилищ обеспечивает водное сообщение со всеми морями европейской части страны, чего не позволяет система сибирских рек (Оби, Енисея и Лены) в АЗРФ.

Особое внимание следует уделить восточному сектору Арктики и развитию там необходимой инфраструктуры. Основными транспортными магистралями в этом регионе являются Транссибирская магистраль (Транссиб) и Байкало-Амурская магистраль на юге, а также СМП на севере. Эти транспортные пути создают базовую основу всех остальных транспортных коммуникаций. От Транссиба до Северного Ледовитого океана (Обской губы) доходит только одна железная дорога: Тюмень - Транссиб - Тобольск - Сургут - Новый Уренгой - Ямбург. Все остальное пространство Восточной Арктики (Западная Сибирь, Якутия, Восточная Сибирь) по сути дела связаны только меридиональными водными путями - главными сибирскими реками и их притоками со всеми присущими им достоинствами и недостатками.

Вся ресурсная продукция Западной Сибири (сжиженный газ и нефть) вывозится отсюда через порт Сабетта по СМП специальными танкерами в Мурманск. Для обеспечения работы порта Сабетта потребовалось осуществить большие вложения в создание 49-километрового морского канала шириной 300 м и глубиной 15,1 м. В настоящее время ведется строительство порта в Харасавэе для обслуживания в том числе шельфовых месторождений Карского моря. При росте объемов производства сжиженного газа (с введением второй и третьей очередей проекта «Ямал СПГ» в 2018 г., а также с реализацией проекта «Арктик СПГ-2») часть продукции планируется отправлять в восточном направлении. Для этого «НОВАТЭК» в бухте Бечевинская (Камчатский край) планирует создать перегрузочный СПГ-терминал. Сюда будут приходить танкеры ледового класса, а дальше в Азию могут уходить простые танкеры без ледового усиления и большей вместимости. 
Важным элементом этой транспортной системы может стать Ямбург. Это единственное место в Восточной Арктике, к которому подходит железная дорога. Однако чтобы этот порт начал работать на полную мощность для снабжения нефтегазовых районов Ямало-Ненецкого автономного округа, нужно провести дноуглубительные работы и довести глубины здесь до 8 м. Кроме того, сама железнодорожная ветка Новый Уренгой - Ямбург, которую перестали эксплуатировать в 2015 г., требует модернизации.

Параллельно с Северным широтным ходом строится автомобильная дорога Надым - Салехард протяженностью 344 км. Улучшается и авиационное сообщение. В последние годы введены в эксплуатацию два новых аэропорта в Бованенкове и Сабетте.

В Восточной Арктике основную транспортную роль играет Енисей, особенно его глубоководные низовья [12]. Достаточно сказать, что естественный глубоководный путь от устья Енисея позволяет морским судам грузоподъемностью 15 тыс. т проникать вглубь материка на 423 км (до Дудинки), а судам грузоподъемностью 10 тыс. т - на 685 км (до Игарки).

Под проводкой ледоколов суда в этой части СМП могут плавать в течение почти всего года. Навигация может прерываться только в конце мая в июне в связи с прохождением пика весеннего половодья и ледохода. Такое обеспечение транспортных возможностей позволило Норильску стать самым крупным индустриальным центром Арктики и превзойти по промышленным показателям такие крупные индустриальные центры, как Мурманск, Архангельск, Воркута и др. По мнению авторов [13], Норильск в перспективе должен стать ключевой базой-центром Норильско-Туруханского акватерриториального производственного комплекса. В случае прокладки Северного широтного хода, который свяжет Северную и Свердловскую железные дороги, в данном комплексе будут освоены новые горизонты богатых на цветные металлы площадей Норильского района. Кроме того, облегчится создание Пайяхского нефтегазового кластера. Впоследствии, однако, «Роснефть» планирует создание собственного экспортного терминала Таналау (первая очередь - к 2023 г. на 7,5 млн т, к 2030 г. до 22 млн т в год) в устье Енисея. На Таймырском полуострове будет также развиваться угледобыча, для чего порт Диксон будет модернизирован под угольный терминал на 20-30 млн т.

Развитие этого промышленного района сдерживается отсутствием надежной круглогодичной транспортной связи между прилежащими к Транссибу южными районами и северными районами, тяготеющими к СМП. Сквозное грузовое судоходство по Енисею в настоящее время является эпизодическим, пассажирский флот для регулярного сообщения представлен судами «Александр Матросов» и «Валерий Чкалов» (рейсы раз в три дня в летнюю навигацию). Такая ситуация может измениться в связи с реализацией комплексного проекта «Енисейская
Сибирь», инициированного в 2018 г. губернатором Красноярского края.

Судоходство на притоках Енисея осуществляется в гораздо более трудных условиях, чем по Енисею. Мешают ограниченная осадка судов, отсутствие специализированного малотоннажного флота, короткий период навигации (по Енисею - четыре месяца, а на большинстве его притоков - от 7 до 20 дней [12]).

Далее на Восток основной транспортной артерией является Лена с притоками. Однако поскольку в среднем течении Лены нет крупных узлов поставки грузов, река используется в основном для северного завоза в улусы Якутии. В 2020-х годах ситуацию может изменить работа обновленной Жатайской судоверфи: в планах - переработка 30-35 тыс. т металла и создание 10 новых судов ежегодно.

В Чукотском автономном округе ряд морских портов и аэропортов реконструируется в рамках государственной программы «Развитие транспортной системы России». Так, значительное развитие получат порт Певек в связи с перспективами разработки Баимской площади, а также порт Беринговский в связи с перспективами освоения Беринговского каменноугольного бассейна [14].

Для основной части восточной Арктики характерны безальтернативность действующих транспортных схем и ограниченность взаимозаменяемости одних видов транспорта другими. Это обстоятельство влечет большие транспортные издержки. Ограниченность времени, доступного для перевозок, вызывает не только значительные затраты, но и дополнительные расходы по созданию сезонных и страховых запасов грузов и их хранению. При распространенных в Арктике сложных транспортных схемах грузы могут задерживаться в пути на очень продолжительное время - до 1-1,5 лет. Специалисты показали, что 60-70\% всех затрат в Арктике связано с транспортом.

На примере анализа развития речных грузоперевозок по сибирским рекам в 1970-1980-х годах можно видеть высокую координацию работ различными ведомствами, стремление максимально загрузить внутренние водные пути в период короткой навигации. В настоящее время для перевозки грузов широко используется автотранспорт, что в связи с его технико-экономическими характеристиками приводит к удорожанию конечной продукции нефти, газа, газоконденсата [15].

Поэтому перспективы дальнейшего освоения и промышленного развития Арктики будут в значительной мере определяться модернизацией существующей и созданием новой транспортной инфраструктуры.

\section{Воздушный транспорт}

Проблему транспортной доступности удаленных районов арктических территорий должен решать воздушный транспорт - как самый скоростной. 
Хотя в стране разрабатываются новые типы самолетов и вертолетов, строятся новые аэропорты и взлетно-посадочные полосы, ситуация с воздушным сообщением в российской Арктике практически не меняется. По-прежнему основным видом воздушных судов остаются самолет Ан-24 и вертолет Ми-8. Многие самолеты этого типа давно должны были быть выведены из эксплуатации. Значительную часть местных рейсов осуществляют очень дорогие, рассчитанные на выполнение оборонных задач массивные вертолеты Ми-8 (стоимость одного летного часа - 300 тыс. руб.). В то же время значительная часть работы могла бы быть выполнена легкими вертолетами, а некоторые работы - легкими самолетами с расширенными возможностями, но их очень мало, хотя расчеты однозначно показывают, что маломоторные самолеты в эксплуатации значительно дешевле даже с учетом затрат на поддержание взлетной полосы. Нет воздушных судов на лыжных шасси. Нет современных аэропортов и соответствующей инфраструктуры.

В АЗРФ действуют разные аэродромы: с искусственным покрытием, грунтовые, с системами светосигнального оборудования, авиаплощадки. Для обеспечения функционирования социально значимых аэропортов на территории АЗРФ созданы четыре федеральных казенных предприятия на базе 16 аэродромов: «Аэропорты Севера» (5), «Аэропорты Чукотки» (9), «Аэропорт Амдерма» (1) и «Аэропорты Красноярья» (1).

С 2015 г. эксплуатируется новый международный аэропорт Сабетта, имеющий статус аэропорта федерального значения и являющийся важным элементом транспортной инфраструктуры масштабного проекта «Ямал СПГ ».

Отечественная авиационная промышленность не выпускает воздушные суда нового поколения, в том числе способные работать в экстремальных условиях Севера - такие, как прошедшие сертификацию семиместные самолеты «Аккорд-201», СМТ-92Т «Турбо-Финист», которые лишь намечаются к производству. Создание же воздушных судов вместимостью до 19 пассажиров пока только в проектах.

Решением проблемы на данном этапе может стать выпуск турбовинтового самолета ТВС-2М, являющегося модернизацией существующих самолетов Ан-2. Это позволит перейти с авиационного бензина на авиационный керосин и существенно повысить комфорт для пассажиров. Выпущено более 10 самолетов, однако модернизированный вариант пока не имеет аттестата летной годности, что сдерживает развертывание производства.

Перспективно использование в Арктике самолетов-амфибий типа ЛА-8 (Самара). Применение здесь самолетов-амфибий позволит существенно повысить авиационную подвижность населения при значительной экономии средств федерального бюд- жета либо при том же финансировании увеличить число населенных пунктов, охваченных авиационным транспортным обслуживанием.

В 2014 г. правительство России утвердило государственную программу «Развитие авиационной промышленности на 2013-2025 годы» (ответственный - Минпромторг России), где есть подпрограмма «Малая авиация», которая вселяет надежду на разработку новых типов летательных аппаратов, необходимых в Арктике, и пополнение авиапарка региональных и местных авиасообщений к 2020-2025 гг.

Состояние авиационного транспортного обслуживания непосредственно влияет на обеспечение безопасности жизни и деятельности в АЗРФ и безусловное исполнение соответствующих прав граждан. Нарастают проблемы с оказанием срочной медицинской помощи в районах Крайнего Севера и приравненных к ним местностях в силу деградации созданной в СССР системы санитарной авиации. Возможность развития таких арктических мегапроектов, как Северный морской путь и Северный транспортный коридор, освоение крупных нефтегазовых месторождений углеводородов, разработка и развитие промышленного производства в Арктической зоне существенно зависят от развития авиационного сообщения.

\section{Заключение}

В «Стратегии развития Арктической зоны Российской Федерации и обеспечения национальной безопасности на период до 2020 года» была поставлена задача создать единую Арктическую транспортную систему, которая должна включать в себя национальную морскую магистраль - Северный морской путь и связанные с ней речные, железнодорожные и автомобильные маршруты и коммуникации со всей присущей им инфраструктурой. Эта система должна обеспечить все необходимые потребности АЗРФ.

Центральной осью всех транспортных путей Арктической зоны России является Северный морской путь. Однако в настоящее время устойчиво работает только его западная часть - от Мурманска до Дудинки. Использование же СМП и всего Арктического морского маршрута в качестве конкурентного международного транспортного коридора между Тихоокеанским регионом и Западной Европой пока задерживается [8]. Следует отметить отсутствие устойчивых меридиональных связей регионов российской Арктики с остальной экономикой страны, что особенно выражено в азиатской части России.

Показано, что ключевые проекты по созданию новых элементов арктической транспортной системы находятся в разных стадиях реализации. По мнению авторов, только с завершением строительства Белкомура, Северного широтного хода, обустрой- 
ства различных участков Северного морского пути можно будет говорить о создании единой транспортной системы в АЗРФ.

Для завершения создания такой системы предстоит преодолевать существенные трудности, связанные с организационными, техническими и финансовыми проблемами. Эффективное развитие транспорта в АЗРФ возможно только в случае высокой координации работ различных ведомств при реализации государственных программ и программ арктических субъектов Федерации.

Народнохозяйственное значение, а также высокая капиталоемкость этих проектов обусловливает большое количество участников, что может привести к несовпадению их интересов и вследствие этого к слабой координации деятельности по их реализации, задержке сроков запуска отдельных объектов. Перспективы развития транспортной системы АЗРФ должны быть увязаны с планами ресурсных корпораций по освоению ключевых месторождений полезных ископаемых, с планами встраивания России в международные транспортные коридоры, а также учитывать тенденции изменения структуры расселения жителей Арктической зоны. Кроме того, функционирование системы существенно зависит от темпов развития арктического судостроения, технологического оснащения арктических навигационных, гидрографических, метеорологических, аварийноспасательных служб.

Важную роль в становлении единой транспортной системы АЗРФ может и должно сыграть развитие механизмов государственно-частного партнерства. Применительно к транспортным проектам арктических субъектов Федерации этот механизм используется пока эпизодически.

\section{Литература}

1. Крюков В. А., Крюков Я. В. Взаимодействие севера и юга Сибири - в основе «управление» мультипликативными эффектами // Вестн. НГУЭУ. 2017. — № 4. - С. 22-27.

2. Клепач А. Н., Разбегин В. Н. Роль транспортных проектов в развитии Арктики и русского Севера // Гос. аудит. Право. Экономика. - 2017. № $1 .-$ С. $121-124$.

3. О состоянии и проблемах законодательного обеспечения реализации Стратегии развития Арктической зоны Российской Федерации и обеспечения национальной безопасности на период до 2020 года. О состоянии и проблемах обеспечения научной деятельности в Российской Федерации в Антарктике: Ежегодный отчет (2017 год) / Совет по Арктике и Антарктике при Совете Федерации Федерального собрания Российской Федерации. - М., 2018. - URL: http://council.gov.ru/media/files/DhrA9 Y46BaPHLySXCkSZGZzqkIQC8jzQ.pdf.

4. Humpert M. The Future of the Northern Sea Route A "Golden Waterway" or a Niche Trade Route / The Arctic
Inst. - Sept. 15, 2011. - URL: http://www.thearcticinstitute.org/the-future-of-northern-sea-route-golden/.

5. Молодиченко Е. В. Проекты АО «ОСК» в целях обеспечения хозяйственной деятельности в Арктическом регионе: [Презентация] // Международный форум «Судостроение в Арктике», июнь, 2018, Архангельск. - URL: http://www.arcticshipbuilding. com/assets/files/Presentation/2018/1\%20MolodichenkoEV.pdf.

6. Григорьев М. Н. Потребности в судах для Арктики, потенциал российских верфей: [Презентация] // Международный форум «Судостроение в Арктике», июнь, 2018, Архангельск. - URL: http://www.arcticshipbuilding.com/assets/files/ Presentation/2018/2\%20GrigorievMN.pdf.

7. Григорьев М. Н. Развитие арктического грузопотока углеводородных ресурсов // Нефтегаз. вертикаль. - 2017. - № 5. - С. 74-86.

8. Чижков Ю. В. Северный морской путь в структуре Арктической транспортной системы // Транспорт Рос. Федерации. — 2017. - № 1 (68). С. 27-32.

9. Капкайкина О. А., Малов В. Ю., Тарасова О. В. Российский транзит: оценка перспектив конкуренции за евроазиатский контейнерный поток // Ситуационная комната как элемент организации экспертного сообщества: задачи планирования и прогнозирования. - Гл. 2.5 / Под ред. Г. А. Унтуры; Рос. акад. наук, Сиб. отд-ние, ИЭОПП СО РАН. - Новосибирск: Издво ИЭОПП СО РАН, 2018. - С. 89-102.

10. Кондратов Н. А. Особенности развития транспортной инфраструктуры в Арктической зоне России // Геогр. вестн. - 2017. — № 4 (43). - С. 68-80. DOI: 10.17072/2079-7877-20174-68-80.

11. Замятина Н. Ю. Транспорт Севера и Арктики: тоска по малым формам. — URL: https://goarctic.ru/live/ transport-severa-i-arktiki-toska-po-malym-formam//. 12. Безруков Л. А. Проблемы формирования транспортной системы Сибирской Арктики // ЭКО. 2018. - T. 48, № 4. - C. 29-47. - DOI: http://dx.doi. org/10.30680/ECO0131-7652-2018-4-29-47.

13. Бондаренко Л. А., Ионова В. Д., Малов В. Ю., Тарасова О. В. Возможности формирования акватерриториально-производственных комплексов (АТПК) в зоне влияния Северного морского пути // Азиатская часть России: моделирование экономического развития в контексте опыта истории / Отв. ред. В. А. Ламин, В. Ю. Малов. - Новосибирск: Изд-во СО PAH, 2012. - C. 219-242.

14. Тарасова О. В., Соколова А. А. Перспективы комплексного освоения Чукотского АО // Мир экономики и управления. - 2018. - Т. 18, вып. 2. - С. 6985. - DOI: 10.25205/2542-0429-2018-18-2-69-85.

15. Щербанин Ю. А. Перевозка грузов по внутренним водным путям России: стратегия развития до 2030 года (новые возможности для нефтегазового сектора) // Науч. тр. ИНП РАН. - 2016. № $1 .-$ C. $291-301$. 